IRSH 59 (20I4), Special Issue, pp. I I-43 doi:I0.IoI7/So0208590I400039X (C) 2014 Internationaal Instituut voor Sociale Geschiedenis

\title{
Contract, Work, and Resistance: Boatmen in Early Colonial Eastern India, I760s-I 850 s $^{*}$
}

\author{
Nitin S INHA \\ Vanbrugh College V/A/22I, Department of History, \\ University of York \\ York YOIO sDD, United Kingdom
}

E-mail: nitin.sinha@york.ac.uk

\begin{abstract}
In the period between the i 760 s and the i 850 s boatmen were the most important transport workers in early colonial eastern India, at least numerically. Unfortunately, they have received little scholarly attention so far. By looking at the regime of work, which surprisingly had strong bases in the notion of contract from as early as the I770s, this article explores the nature of work, work organization, and resistance by boatmen. It argues that although work was structured according to the wage or hire-based (thika) contract regime, the social, political, and ecological conditions in which contract operated were equally crucial. The centrality of contract was premised upon how effectively it was enforceable and, in fact, historically enforced. Boatmen being one of the most important "native" groups with which the British were left on their often long journeys, this article suggests that contract helps to understand the formal "structure of work", and the minute details of the journey help to understand the "world of work", of which clandestine trade, weather, wind, rain, torrents, tracking, mooring, internal squabbling, and, not least, preparing food were some of the main components.
\end{abstract}

The ecology and political economy of eastern India perhaps made boatmen the most important transport workers in early colonial India. This region is criss-crossed by a variety of bodies of water that historically made rivers the standard means of communication throughout the year. To a great extent, the ascendancy of the English East India Company (EIC) depended on the long-distance trade in imperial commodities such

\footnotetext{
* This paper is part of the larger project "The Ganga: Landscape, Community, Religion, 1760s-I960s", which was funded by the Federal Ministry for Education and Research, Germany. The archival research was carried out when based at ZMO, Berlin. The paper was written under the fellowship programme of IGK Work and Human Life Cycle in Global History, Berlin. I am thankful to all three of them for institutional support. The paper has organically grown through numerous discussions with Nitin Varma and help provided by Maria Framke.
} 
as opium, indigo, textiles, salt, and saltpetre. This required a stable system of transportation to and from Calcutta. In I780, James Rennell had estimated that about 30,000 boatmen were involved in the task of inland navigation in Bengal. ${ }^{\mathrm{I}}$ Subsequently, a text published in ${ }^{8} 836$ gave a figure of 350,000 for the whole of the river Ganga. ${ }^{2}$ Even if these figures seem inflated, the fact that boatmen remained an important group of transport workers is beyond dispute. This is also corroborated by looking at a range of visual and textual accounts (both administrative and private) in which they start appearing early on.

The Ganga, connecting eastern and northern India, was the imperial highway both in Mughal and early colonial times. A number of European trading companies, native chiefs, and zamindari (landed) elites required the services of boatmen; this article discusses their relationship with the EIC. The Company required their services for a number of reasons: for conveying newly arrived cadets and officials to their joining stations; for transporting goods such as saltpetre, opium, indigo, textiles, cotton, and other bulk commodities such as grains; and for carrying troops. The sheer variety of boats, depending on the nature of merchandise, weight, and oars, proves that boating was an extremely diversified and specialized profession. ${ }^{3}$ Further, as the navigability of some of the channels, streams, and rivers changed constantly, the boatmen's skill was complemented by their close and precise knowledge of the waterways. ${ }^{4}$

In south Asian transport and labour historiographies, transport workers have received little scholarly attention. ${ }^{5}$ Only in very recent times have some of the groups become the subject of study. ${ }^{6}$ By looking at boatmen's

I. Sabyasachi Bhattacharya, "Eastern India I", in Dharma Kumar (ed.) (with the editorial assistance of Meghnad Desai), The Cambridge Economic History of India, II, c.1757-c.1970 (Cambridge, 1983), p. 27 I.

2. Memoir on the Agricultural and Commercial Capabilities of Bengal in Observations with Reference to the Establishment of the East India Sugar and Agricultural Company, Extracted from Various Sources, with Original Calculations, and Remarks (London, I836), p. 5.

3. Robert L. Hardgrave, Jr, Boats of Bengal: Eighteenth Century Portraits by Balthazar Solvyns (Delhi, 200I).

4. On the changing courses, see Walter S. Sherwill, "Report on the Rivers of Bengal", in Selections from the Records of the Bengal Government (Calcutta, I858), pp. I-I9.

5. Railway workers have attracted the most attention by far, but for them also the scope of future research is immense. Two important works on India's railways are Ian J. Kerr, Building the Railways of the Raj, I850-1900 (Delhi, 1995); and Laura Bear, Lines of the Nation: Indian Railway Workers, Bureaucracy, and the Intimate Historical Self (New York, 2007).

6. Recently, Chitra Joshi looked at convicts, dak runners, and palanquin bearers, all associated with road transport: Chitra Joshi, "Dak Roads, Dak Runners, and the Reordering of Communication Networks", International Review of Social History, 57 (2012), pp. I69-189; idem, "Fettered Bodies: Labouring on Public Works in Nineteenth-Century India", in Marcel van der Linden and Prabhu P. Mohapatra (eds), Labour Matters: Towards Global Histories, Studies in Honour of Sabyasachi Bhattacharya (New Delhi, 2009), pp. 3-21. Another group characterized 
regime of work, which from as early as the I770s had a strong basis in the notion of contract, I will examine the nature of work, work organization, and resistance by boatmen. In doing so, this article also contributes to the few existing studies on labour in the early colonial period.

\section{CONTRACTS FOR TRANSPORTING TROOPS AND IMPERIAL COMMODITIES}

In the I770s, within the government establishment, the army's requirement for boats was greatest. In $177 \mathrm{I}$ and 1772 the boat establishment cost Rs 307,922 and Rs 352,264 respectively. 7 This was the cost of the fixed boat establishment. In $\mathrm{I} 772$, in addition to this, boats hired for military services cost Rs 214,926, thus bringing total expenditure to Rs 567,190. In the same year, a brigade which was on the march for four months cost Rs i 8,620. The EIC therefore decided to reduce the fixed establishment and procure boats, when needed, through a system of public tenders and contracts. Arguably, the contract system had been practised at an earlier date, but due to "many difficulties and inconveniences which were found to attend it" it was discontinued. ${ }^{8}$

The reduced establishment of five budgerows (a contemporary anglicized word for one of the most popular boats in Bengal, the bajrab) of eighteen oars, fifteen boats for magazine and military stores, twelve boats for the hospital (carrying the sick and supplies), twelve common transport boats, and five small boats for each brigade (there were three brigades altogether) was proposed. To reduce the cost further, private trade using these boats was strictly prohibited; the brigades were asked occasionally to assist each other, when required; and the civil officials were promised cash in lieu of their boat expenses. ${ }^{9}$ Mobility itself was restricted due to the seasonal navigability of rivers. In the winter months, the Hooghly

as transport workers are the banjaras. Both their mobility and criminality has been explored: Robert G. Varady, "North Indian Banjaras: Their Evolution as Transporters", South Asia, 2:I-2 (1979), pp. I-I 8; Ian J. Kerr, "On the Move: Circulating Labor in Pre-Colonial, Colonial, and Post-Colonial India”, in Rana P. Behal and Marcel van der Linden (eds), Coolies, Capital, and Colonialism: Studies in Indian Labour History (Cambridge, 2007), pp. 85-109; Meena Radhakrishna, Dishonoured by History: "Criminal Tribes" and British Colonial Policy (Delhi, $200 \mathrm{I})$; Nitin Sinha, "Mobility, Control and Criminality in Early Colonial India, I760s-I 8 50s", Indian Economic and Social History Review, 45 (2008), pp. I-33.

7. Home Public [hereafter, HP], B, 2I June 1773, no. is. Subsequent information is based on this source. The HP files used in this article are from the National Archives of India, New Delhi.

8. Ibid.

9. For military officials, too, the rules were tightened. The commanding officers of brigades and detachments were not allowed to permit officers under their command to go to Calcutta on leave or absence without the governor's prior permission. If permitted, such passages were not allowed at the Company's expense; HP, Consultation 7, June I773, nos 29-30. 
passage was difficult to navigate; the boats usually took the circuitous route round the Sundarbans. It was therefore decided not to send any stores from the Bengal Presidency up the country between 20 November and 30 June of the following year. It was also pointed out that usually in these months troops marched over land, which rendered transporting them by water unnecessary. ${ }^{10}$

The exact effect of these reductions and restrictions on the employability of boatmen is difficult to calculate, but it is clear that the reduction in the number of boats must have led to a significant reduction in the overall strength of the crews. Before the proposed reduction, the total estimate of boats in service was: 63 budgerows, I 20 large boats, I00 small boats, and 6 Dacca pulwars. The cost of hiring all of these was Rs 20,060 per month. In contrast, the reduced number of boats was supposed to cost Rs 9,870 per month. For large boats, the rate of hire was also reduced, from Rs 65 to Rs 60 per boat. ${ }^{\text {II }}$ For the 18 -oared budgerows alone, this reduction meant that the total number of men employed decreased from I, I 34 to 270 , i.e. to less than one-quarter.

In addition, there is strong evidence to suggest that a majority of those who were employed under the new contract system ceased to enjoy better wages. For this, the contracts have to be considered. In 1774, a contract was finalized between the EIC and Mr J. Fraser, who had been living in India for seven to eight years and was described as a "peaceable and inoffensive subject". ${ }^{22} \mathrm{He}$ was contracted to provide for II6 boats of 4 different varieties, and therefore, was required to maintain "upwards of 5000 people, orphans and coolies". ${ }^{3}$ However, a comparison of his tendered price with that of the government's estimation is revealing: for one budgerow "fitted with I 8 oars and manned with one manjee, two golleahs and eighteen dandies completely found and equipped for service" he had offered the monthly hire rate of Rs I00. This was way below the rate of Rs I60 as fixed or estimated by the government. It is unclear how Fraser offered to supply the boats and maintain the crew at his proposed rate.

I0. HP, B, 21 June I773, no. I6. The employment of boatmen obviously varied according to the season and the amount of rain. See HP, October I 822, no. 7, and HP, I August I 822, no. I0, on the extra hire of boatmen during the rainy season.

II. HP, B, 2I June I773, no. I5. It must have taken some time for the reduction to come through. In December 1773 the total number of boats employed in the military department was eight budgerows (ranging from twenty-four to fourteen oars) and fifty-six boats (from fourteen to six oars); HP, C, I6 December I773, no. I (B).

I 2. HP, Consultation, 6 January I 774 , no. I I.

13. Ibid. Reference to the use of orphans is quite striking and singular in the sources used in this article. Also, there is no further discussion of this in the letter written by Fraser and the contract approved by the Chief of Patna. In all probability, it could mean a pool of orphans available in the local labour bazaar of Patna or other riverine districts who could have been hired on low wages. 
According to a government calculation, for one budgerow with eighteen oars the monthly maintenance and labour charges would amount to Rs I I 3, calculated in the following manner: monthly repair charge at Rs 2 an oar $(18 \times 2=36)$ and monthly pay of Rs 5 and 4 to a manjhee ${ }^{14}$ and a dandy ${ }^{\mathrm{IS}}$ respectively $(\mathrm{I} \times 5+\mathrm{I} 8 \times 4=77){ }^{{ }^{16}}$ Without adding the cost of two golleabs, ${ }^{17}$ the labour and maintenance costs alone exceeded the Rs roo being proposed.

The sources immediately related to this contract do not explain this conundrum. There can be two possibilities: either Fraser's offer of Rs ioo did not include repair and labour costs (just the boat hire); or the maintenance of boats was not taken very seriously and the monthly wages of the boatmen were significantly reduced to increase profit margins. The wording in the contract that Fraser, "notwithstanding the difficulty", would maintain upwards of 5,000 people is revelatory and implies that the second reading could be correct, even more so since a monthly hire rate of Rs ioo just for boats seems untenable in the light of other evidence from the early nineteenth century. Additionally, these sources also indicate that dandies were likely to receive almost half the wage the government had fixed or estimated. To quote from the author of a two-volume guide for newcomers to India, the wages varied "from two and a half to three and a half, or even four [Rs]; all according to the kind of the boat, and the dignity of the employer". ${ }^{8}$

I4. The manjhee was the master or steersman of a boat; Henry Yule and A.C. Burnell, HobsonJobson: A glossary of colloquial Anglo-Indian words and phrases, and of kindred terms, etymological, historical, geographical and discursive, new edn by William Crooke (London, 1903), p. 558.

I 5. The word dandy, meaning boatman, was peculiar to the river Ganga in the Hindi and Bengali languages; the word derived from dandi or dand, meaning a staff or an oar; Yule and Burnell, Hobson-Jobson, p. 296.

16. Cost calculated from HP, B, 2 I June 1773 , no. is.

17. Surprisingly, Hobson-Jobson has no entry for golleah. Nonetheless, other contemporary sources do refer to this workforce: Thomas Williamson described the manjhee as the steersman and the golleab as the bowman; A. Deane, who provided a list of necessary words and commands for river travel, described the golleab as the steersman, and the manjhee as the captain of the boat crew. See Thomas Williamson, The East India Vade-Mecum; or, Complete Guide to Gentlemen Intended for the Civil, Military, or, Naval Service of the Hon. East India Company, 2 vols (London, I 810), I, p. 283; A. Deane, A Tour through the Upper Provinces of Hindostan; Comprising a Period between the Years I 804 and I8I 4: with Remarks and Authentic Anecdotes to which is Annexed, a Guide up the River Ganges with a Map from the Source to the Mouth (London, I823), pp. 290-291.

I8. Williamson, The East India Vade-Mecum, I, p. 284. A Christian missionary who travelled up the river in 1834 mentioned that the general monthly wages of a dandy and a manjhee were Rs 3 and Rs 4 respectively; John C. Lowrie, Travels in North India [...] (Philadelphia, PA, I 842), p. 9I. Balthazar Solvyns also gave the figure of Rs 3 a month for the dandy. For the ill-fed and ill-paid conditions of "boys" employed on towboats helping incoming ships to enter into the Ganga and Hooghly, see Hardgrave, Boats of Bengal, p. I 16 ; for reference to dandies' wages, see p. 30 . 
One thing that clearly emerges from this discussion is that boatmen, especially dandies, received lower wages under a private contract system than under the direct hiring done by the government. Also, some form of personal perquisites that these men would have obtained through the provision of repair charges might have ceased to exist under the private contract system.

The choice of speculative phrases such as "might have", "must have", and "would have" is deliberate. It reflects the scarce and sketchy nature of the materials one is dealing with in constructing the history of work and work relationships between boatmen and their employers (the EIC). It was probably this, and the seductive strength of the "continuity" framework to understand the early colonial period, that led Michael Anderson to claim that the question of labour in this period did not become an independent topic of concern for early colonial administrators. According to him, they followed the available pre-colonial frameworks of kin, caste, family, and village communities to "manufacture the consent for highly coercive labour processes". ${ }^{19}$ Ravi Ahuja's work on early colonial Madras convincingly refutes this argument and brings back the focus on the colonial state in not only advancing a labour policy but also, through its interventionist practices, shaping labour relationships. ${ }^{20}$

One such instrument was the contract between the worker and the employer. Once again, turning to another of Ahuja's essays, it becomes clear that the notion of contract as premised upon free wage labour and an agreement supposedly formed between formally equal parties was not the only form of labour relationship. Heterogeneity, ranging from slavery and forced labour to that of contracted work, was the hallmark of early colonial labour relations. ${ }^{21}$ This kind of observation is possible when one covers a range of occupations, as Ahuja did. Working on a specific group of workers has its advantages and limitations. One advantage is the clear identification of the centrality of the contract system, at least for those boatmen who worked directly for the EIC. In fact, it was also crucial in the sphere of private travelling (as elaborated in the next section). One of the limitations, however, is the impossibility of determining the "coloniality" of this practice. Given the lack of studies on pre-colonial times, it would be highly dubious to claim that the contract system for boat hiring was a colonial novelty.

19. Michael R. Anderson, "Work Construed: Ideological Origins of Labour Law in British India to 1918", in Peter Robb (ed.), Dalit Movements and the Meanings of Labour in India (New Delhi, I993), p. 90.

20. Ravi Ahuja, "The Origins of Colonial Labour Policy in Late Eighteenth-Century Madras", International Review of Social History, 44 (1999), pp. I 59-195.

21. Idem, "Labour Relations in an Early Colonial Context: Madras, c.1750-1800", Modern Asian Studies, 36 (2002), pp. 793-826. 
Prabhu Mohapatra has recently looked at the working of contracts in the production of textiles and indigo. ${ }^{22} \mathrm{He}$ argues that although contracts were theoretically based on the idea of free choice, they contradictorily induced the production or reproduction of unfree labour conditions. Before teasing out the implications of the contract, in the context of this article it is important to ask why the government resorted to contracts for procuring boats. ${ }^{23}$ Evidently, it wanted to cut its expenses. In other words, it intentionally used contracts as a cost-saving mechanism, with repercussions for the wages of boatmen.

At the same time, it is equally necessary to ask how far this system helped the state beyond mere cost-saving. To what extent were contracts successfully enforceable and actually enforced? It is important to realize that the system was subject to the political and administrative limitations of the early colonial state; because of the nature of this occupation seasonal and ecological constraints were also significant. The fundamental question to begin with is: did the parcelling of the authority and responsibility which contracts engendered (for instance, from the military board of the EIC to Mr Fraser) help the Company to secure boats easily? Complaints, in any case, about the insufficient availability of boats were frequent. In $178 \mathrm{I}$, the revenue chief at Patna complained about the unavailability of boats for transmitting the treasury (district revenue) to Calcutta. This might have been because of the season; it was already April and the hot season had set in. ${ }^{24}$ In another incident in 1799 , fifty-two boats laden with grain for the Allahabad fort were detained at Patna. The boats were sailing under the charge of the Company and under the command of one naik (police supervisor) and six sepoys, but a dispute among manjhees caused a hold-up. ${ }^{25}$

For transporting high-end commodities such as saltpetre and opium, either contractors or manufacturers were made responsible. The transportation depended on how the production was organized. Opium serves as a good example to show the indeterminate position of the colonial state. ${ }^{26}$ The EIC in Bengal had enjoyed a monopoly of the trade in opium

22. Prabhu P. Mohapatra, "From Contract to Status? Or How Law Shaped Labour Relations in Colonial India, 1780-1 880", in Jan Breman et al. (eds), India's Unfree Workforce: Of Bondage Old and New (New Delhi, 2009), pp. 96-i 25.

23. This discussion of the notion of contract is unrelated to Mohapatra's point concerning the contradictory nature of contractarian philosophy in producing unfree labour. My intention is to situate contract within the prevailing economic, administrative and ecological settings of the late eighteenth and early nineteenth centuries, which, by any estimate, were "dynamic".

24. John Francis William James, Selections from the Correspondence of the Revenue Chief of Bihar, $178 I_{-1}-1786$ (Patna, I919), p. 65.

25. Kalikinkar K. Datta (ed.), Selections from Unpublished Correspondence of the JudgeMagistrate and the Judge of Patna, I790-I857 (Patna, 1954), p. 192.

26. The following account is based on ibid., pp. $25-28$. 
since $176 \mathrm{I}$. In 1765 , this trade and its profits were put in the hands of the Company's Patna factory. However, in 1773 the Governor-General Warren Hastings granted the contract to two natives, Meer Muneer and Ramsharan Pundit. Due to their irregularities and the oppression of the raiyats (peasants), on I I July 1785 the EIC resorted to the public sale of the contract to the highest bidder for a term of four years. The revenue from the opium trade declined. Its quality also reportedly suffered. As a result, in 1797 the contract system was abolished. In I799 an agency of a covenanted servant of the Company was established. The Company began to deal directly with opium manufacturers through its servants. Under the contract system, the seventh clause made it clear that "the charges of package and manufacture and the charges and risk of transportation and delivery are to be on account of the contractor". ${ }^{27}$ The manufacturers privately arranged to transport opium to Calcutta. Boats were procured on the basis of contracts with manjhees.

Although any delays may thus appear to have been a private affair, saltpetre and opium manufacturers frequently petitioned the EIC. These petitions reveal that that the contract did not ensure efficacy. In I 826 one Ramdayal, a saltpetre manufacturer based in the United Provinces, petitioned the EIC resident at Lucknow, who then forwarded his complaint to the magistrate at Patna. In the petition, Ramdayal accused manjhees of holding up his boats at Patna even after they had been paid for in full and contracted to unload the saltpetre in Calcutta. ${ }^{28}$ In another case, from Bihar, the boats contracted by the EIC for transporting saltpetre to Calcutta were pressed into service by private merchants based at Patna. ${ }^{29}$

The first example is of the private contract; the second involves the state. Both relate to disputes over and deviations from the terms of the contract. Both show the complexity of the socio-economic and political set-up in which the contract worked. Its successful realization depended upon different stakeholders involved in the production and transportation of commodities. A Company monopoly in the trade of certain commodities existed alongside the private trade clandestinely carried in those very commodities and in others for which private traders also needed boats. However, these cases also highlight the way the state authorities were drawn into resolving disputes. Contracts of a private nature did not mean the marginality of the state. ${ }^{30}$ The reasons why the state got deeply involved were twofold. First, even if the matter related to a private contract, the nature of commodities (usually the EIC monopoly ones)

27. Idem (ed.), Selections from the Judicial Records of the Bhagalpur District Office (I792-I805) (Patna, i968), p. 37.

28. Idem, Selections from Unpublished Correspondence.

29. Ibid., p. 168.

30. As has also been convincingly shown by Mohapatra, "From Contract to Status?". 
demanded direct state action. Walter S. Sherwill's account of the production and transportation of opium from the Patna factory is illustrative. The Opium Fleet, as he called it, was "preceded by small canoes, the crews of which sound the depth of water, warn all boats out of the channel by beat of drum, and proclaim that the Opium of the "Companee Bahadoor' claims a passage down the river". ${ }^{3 \mathrm{I}}$ The state directed the local authorities to prevent private merchants from seizing the Company's contracted boats. Second was the notion of the contract itself, which was based upon the twin principles of parcelling authority and responsibility on the one hand but drawing upon the state's enforcing authority on the other.

The impulse to ensure the enforcement of the contract demanded that the state play an active role. Mobility of troops was of crucial political importance, and, even when contracted, this remained an active field of state engagement. It is worth following the debates closely to see what effect the state's measures had on the workforce. The civil authorities of the Gangetic districts complained about the frequent irregularities and improprieties committed by military officials when troops passed through. ${ }^{32}$ The army needed coolies, boatmen, boats, and supplies, which they forced the neighbouring villages to provide, often without making adequate payments. This led to peasants deserting the villages. The military complained about the shortage of workers, but civil officials drew an interesting parallel by pointing out that private individuals did not complain about the shortage of coolies or dandies. Clearly, responsibility for this highhandedness was placed at the door of the military.

The government took notice of such complaints and framed a regulation in 1806 to assist both troops and private travellers. ${ }^{33}$ It directed collectors (a civil authority in the district) and magistrates (a police authority) to help in providing troops with supplies but also in ensuring that any damage done by them should be enquired into and adequately compensated for. A native official was deputed to supply bearers, coolies, boatmen, carts, and bullocks from landholders, farmers, and other relevant persons. The cost of labour and commodities provided for was

3I. Walter S. Sherwill, Illustrations of the Mode of Preparing the Indian Opium Intended for the Chinese Market, from Drawings by Captain Walter S. Sherwill (London, 1851), text opposite "The Opium Fleet".

32. Datta, Selections from the Judicial Records, pp. 363-364.

33. "Bengal Regulation XI of I 806", in F.G. Wigley (ed.), The Eastern Bengal and Assam Code, 3 vols (Calcutta, 1907), I, pp. 87-93. I am grateful to Prabhu Mohapatra for extensively discussing this piece of regulation with me, and for pointing out that this regulation needs to be seen as part of the colonial state-formation as reflected in the contesting authority between the civil and military branches. I agree with him; in fact, I would tentatively extend his argument by claiming that this regulation also shows how control over the workforce was a crucial site of that contestation and processes of state-formation. 
calculated on the basis of the prevailing bazaar prices. The police authorities were strictly forbidden (leading to dismissal, if found guilty) "to compel any persons not accustomed to act as bearers, coolies, or boatmen", or to furnish any bullocks or carts kept for private use or exclusively for agricultural purposes. Attempts to protect the workforce (coolies and boatmen) and raiyats (by protecting them against military highhandedness) and ensuring the smooth passage of the troops and individuals were the twin objectives of this regulation. The market played a crucial role. The cost of hire was to be market-based. Should the coolies and boatmen desire, they could enter into a "voluntary exchange" for distances exceeding the jurisdiction of the mediating district official. However, this was to be regulated and enforced by the state. Crucially, in the case of private individuals (both European and native), the police could demand that they give boatmen full or partial advance payment. Refusal to do so meant denial of government assistance.

Shades of freedom, protection, and violation were enshrined in this regulation and more broadly in conceptual categories such as the market and contract as they historically unfolded through the state's regulative measures. Adherence to the practice of market rate and wilful exchange was tempered with the administrative and political demands of a state that was still in the process of stabilizing itself. As a result, the apparent benevolence of the state in protecting the workforce intensified the "highly injurious practice" of begari (forced labour) because state officials were invested with the authority and responsibility to provide men and material for convenient passages of troops and individuals. ${ }^{34}$ It can be seen as an abuse of authority, or the limitation of a state that failed to realize its ideological objectives.

Another way of looking at it is by recognizing the centrality of labour mobilization in the state-formation process, in which the regulative mechanisms of the state not only shifted and changed but also produced unintended results. There remained an indistinct zone between regulations and practices, which explains why, in spite of the regulative commitment to observe adequate payment and compensation, and also not to indulge in unnecessary force, the practice of begari became widespread. The clause that purported to punish subordinate state officials for the forceful extortion of labour seems to have had little effect. However, the structure of command and organization for facilitating help as enshrined in this regulation itself provides clues as to why the fuzziness would arise in the first place. On receiving requests from military commanders, the

34. "Bengal Regulation III of 1820 ", in Papers Relating to East India Affairs: viz. Regulations passed by the Governments of Bengal, Fort St George, and Bombay, in the Year I 820 (London, I822), pp. 6-7. 
collectors would issue "necessary orders" (with the provision of fines for disobedience) to "landholders, farmers, tahsildars and other persons in charge of the lands through which the troops are to pass" to arrange for supplies. ${ }^{35}$ A "creditable native officer" would accompany the troops to make sure that men and material were duly provided; in the case of difficulties, he would seek the assistance of the nearest police officer. Two things are noteworthy here: first, nowhere in the regulations was the phrase "necessary orders" explained, meaning that the group of providers (landlords and others) had no opportunity of saying "no". Second, although the whole organization was done under civil authority, the onthe-spot resolution of difficulties through the involvement of police authority might have opened the space for the temporary criminalization and coercion of a reluctant workforce. ${ }^{36}$

In 1820 , therefore, the authority vested in local officials to provide men (coolies and boatmen) was rescinded. That marked the official termination of the practice of begari but it does not mean that historical reality would have changed overnight. Rather, it appears that the state compensated for this abolition with a regulation strengthening control over the providers. In I 825 , it passed another regulation that made any "wilful neglect or disobedience" (which had to be proved to the "satisfaction" of the collector) on the part of "landholder, farmer, tahsildar and other person" in providing supplies (including boats) punishable, not criminally but through the imposition of fines not exceeding Rs I,000.37

\section{PRIVATE TRAVELLING AND CONTRACTS}

While individuals like Fraser became contractors for supplying boats to the government, business agencies sprung up in Calcutta to organize up-country travel for both officials and non-officials. On a typical up-country trip from Calcutta on a budgerow (of sixteen oars) usually accompanied by a luggage boat, a cook boat, and also often separate boats for horses and servants, the crew altogether consisted of thirty to forty men. ${ }^{38}$

The widespread practice of river travel must have created lucrative business opportunities and rivalry. As early as $\mathbf{1 7 7 4}$, the government had to put out a public disclaimer declaring that it had not offered any contract

35. "Bengal Regulation XI of I 806", in Wigley, The Eastern Bengal and Assam Code, I, p. 88. 36. This is one way of understanding the "privatisation of regulation" as pointed by Chitra Joshi in "Histories of Indian Labour: Predicaments and Possibilities", History Compass, 6 (2008), pp. 439-454, 447-448.

37. "Bengal Regulation VI of I825", in Wigley, The Eastern Bengal and Assam Code, I, pp. $22 \mathrm{I}-223$.

38. By one estimate, it could reach roo, excluding an equal number of servants; Hardgrave, Boats of Bengal, p. 19. This seems inflated, though. 
or exclusive privilege to one Messrs Share and Dellial. It was forced to do so to steer clear of the complaints made regarding the supply of boats. ${ }^{39}$ Organizing travel through an agency was in fact recommended; it supposedly provided security against dandies' desertion, “a circumstance by no means unusual on this voyage". ${ }^{\circ}$ The traveller paid the agency in advance; the boatmen also received one-half of their payment in advance. Advance payment was also an established practice for sending troops and commodities. ${ }^{4 \mathrm{I}}$ The difference in the case of private travelling, therefore, was the absence of the state as a contracting party. However, as seen above, it was not entirely absent; it actively tried to secure the comfort of the travellers. Also that native officials were given the power to direct travellers to pay boatmen in advance might be recalled.

For private travellers, the contract system worked in two ways. First, according to the thika (literally, a contract, similar to the system of piece wages) given for a said amount according to the distance, with provisions for demurrage; and second, a monthly hire of the vessel, usually at the rate of Rs io an oar. In both cases, "the person hiring has nothing to do with the pay, or provision, of the several men employed in navigating the vessel". ${ }^{2}$ Deane, in her guide up the river Ganga, mentioned that although a budgerow could be hired at a monthly rate varying from Rs 97 to Rs 176 , the one fitted with sixteen oars cost Rs i 57 a month, thus almost corroborating the practice of Rs Io an oar. ${ }^{43}$ I will return to the relationship between these contracts and work, but before that an introduction to the variety of labour forms that existed within the boat is necessary.

There were three types of worker that shared the space of the boat. The manjhee, or the steersman, was the highest ranked. His pay was between Rs 5 and $7 .{ }^{44}$ Being the steersman, he was the leader of the crew. Williamson writes about him: " $[\mathrm{K}]$ nowing that his services cannot be dispensed with, [he] will, in most cases, adhere to his way of thinking, until peremptorily compelled by the master's interference, to submit to orders; or overcome by absolute force." ${ }^{45} \mathrm{He}$ also established the superiority of his position by claiming the forepart of the budgerow, which he generally considered to be his privilege. ${ }^{46} \mathrm{He}$ was also responsible for the conduct of the dandies. However, Williamson points out that each of the crew had his

39. HP, C, 27 June 1774 , no. 6.

40. Deane, A Tour through the Upper Provinces of Hindostan, p. 269. Deane had recommended Messrs Barber \& Co. at the Old Fort Ghaut in Calcutta to the newly arrived Company employees.

4I. HP, Consultation, I 3 January I772, no. 2 (B).

42. Williamson, The East India Vade-Mecum, II, pp. 368-369.

43. Deane, A Tour through the Upper Provinces of Hindostan, p. 269.

44. Discrepancies existed; see n. I7.

45. Williamson, The East India Vade-Mecum, I, p. 284.

46. Ibid., II, p. 377 . 
own opinion and it was not always easy for the manjhee to enforce his wishes. Travellers frequently wrote of the abuse the manjhee and the crew showered at each other during the commotion of setting sail or tracking. ${ }^{47}$

Next in the hierarchy came the golleah, or bowman, whose pay was between Rs 4 and 5. Working with a bamboo pole, golleabs kept "the boat from running against the bank, or upon shoals". ${ }^{8}$ An interesting passage brings out the nature of their work:

Those who have not witnessed the dexterity of this class of people, and the rapidity with which they recover their poles, so as to make repeated resistances in dangerous situations, can form no idea of the strength, activity, and judgement, necessary to qualify a man for this arduous situation. Often the fate of a boat depends on the certainty of the goleeab's throw $\left[\ldots . . .{ }^{49}\right.$

Dandies, the actual rowers, were in significant numbers on the boat. They were hired on contract; thika-dandies, as Williamson called them, were procurable at river ghats. In all probability, each manjbee had his set of preferred dandies and recruited them on getting a contract. The fact that the person hiring the boat was not responsible for pay and provision suggests that for dandies the system of contract worked through the intermediary position of the manjhees. ${ }^{50}$

A rather rare and occasional presence was that of a fourth group, called khalasies. The khalasie was a generic labouring term (very much like coolie) to describe those primarily engaged in the transportation of army equipage in the department of the quartermaster-general. When employed on the budgerow they were "confined entirely to the aquatic equipages of great men".S Interestingly, they found it beneath their dignity to row a boat unless it happened to be a "jolly-boat furnished with oars on the European plan". ${ }^{2}$

In addition to these four types, another internal differentiation existed on the basis of employment. The government had a retinue of boats for the movement of the Governor-General and his entourage. The main fleet

47. Edward Ward Walter Raleigh, Mss. Eur. D 786, p. 4, British Library. All the Mss. Eur. sources used in this article are from the British Library.

48. Williamson, The East India Vade-Mecum, I, p. 285.

49. Ibid.

50. For certain commodities and services such as jute, textiles, tea, and lascars, the role of intermediaries (variously called sardars, muqaddams, jobbers, and serangs) is well explored in the historiography. Sources relating to boatmen are too sparse to construct a detailed history of the manjhees' role as intermediaries. This, therefore, lies outside the scope of the present article. 5. Williamson, The East India Vade-Mecum, I, p. 283.

52. Ibid. Wealthy Europeans and natives kept their own richly ornamented boats with handsomely dressed crew. Some of them, such as the Morphunky (a peacock-headed boat), were typical pleasure boats; "jolly boats" could be a reference to those, and khalasies, who are said to have worn clothes and jackets of English manufacture, might have drawn pride from this association; Hardgrave, Boats of Bengal, pp. 7, 25; Williamson, The East India Vade-Mecum, I, pp. $28 \mathrm{I}-283$. 
consisted of the Governor-General's budgerow (the state yacht), called the Sonamukhee; an attendant state barge, the Philcharee; the state band boat, the Bon Vivant; a large mess boat, the Elvira; and many other rowing boats (bauleabs). ${ }^{53}$ When the decision to sell off the Philcharee and some of the rowing boats was taken in I 828-1829, a number of the boatmen were transferred to other boats and some discharged and given a pension. ${ }^{54} \mathrm{~A}$ list of pensioners gives some interesting details. First, all boatmen were aged fifty to sixty; barring a few, all of them had been employed in the I790s, thus signifying an average service career of more than thirty years. And secondly, family played an important role. Some of them worked together with their brothers; others were substituted by their brothers when on short leave. ${ }^{55}$ The difference in salary from other boatmen is noticeable: a manjhee who would otherwise receive anything between Rs 4 and 7 got Rs io per month, and a dandy, who would normally receive anything between Rs 2 and 4, was paid Rs 4 and 8 annas. Better pay obviously implied a better pension too.

In a significant revisionist intervention, Mohapatra has challenged the earlier argument put forward by Bernard Cohn that colonialism engendered a movement from social status to contract. ${ }^{56}$ The employment-based division among boatmen corroborates his point. The differential status arose because of the nature of employment shaped through active state policies, such as pension, and not through any caste or kinship ties. The two images below illustrate the contrast between dandies working under the two different systems.

To summarize, different types of contractual arrangement (if not the contract per se) structured the work regime of boatmen. One existed directly between the Company and the boatmen, another between the Company and wealthy and enterprising individuals. The third existed between agencies and private individuals, the fourth between agencies and the manjhees. For dandies, another level existed between them and the manjhees. Having said this, it is equally important to bear in mind that the ways in which merchants, traders, travellers, and the state tried to enforce the contract was highly complex and an arena of intense negotiation between them and the boatmen. The normative centrality of contract

53. The Sonamukhee [golden-faced] was built during the period of Warren Hastings (1773-1785); the Philcharee [elephant-headed] in I8 I3. On the latter, see HP, I7 July I 828, nos I4-15, and HP, I8 September I828, nos 19-23. See also The European in India; From $A$ Collection of Drawings, by Charles D'Oyley [...] with a Preface and Copious Descriptions, by Captain Thomas Williamson [...] (London, I8 I3), Plate XII and its accompanying text. Edward Walter Raleigh, who was part of this fleet, provides an interesting account in his diary; Mss. Eur. $\mathrm{D} 786$.

54. HP, Consultation, I4 July i 829 , no. I I.

55. HP, Consultation, 26 February I 829 , no. $2 / 4$.

56. Mohapatra, "From Contract to Status?". 


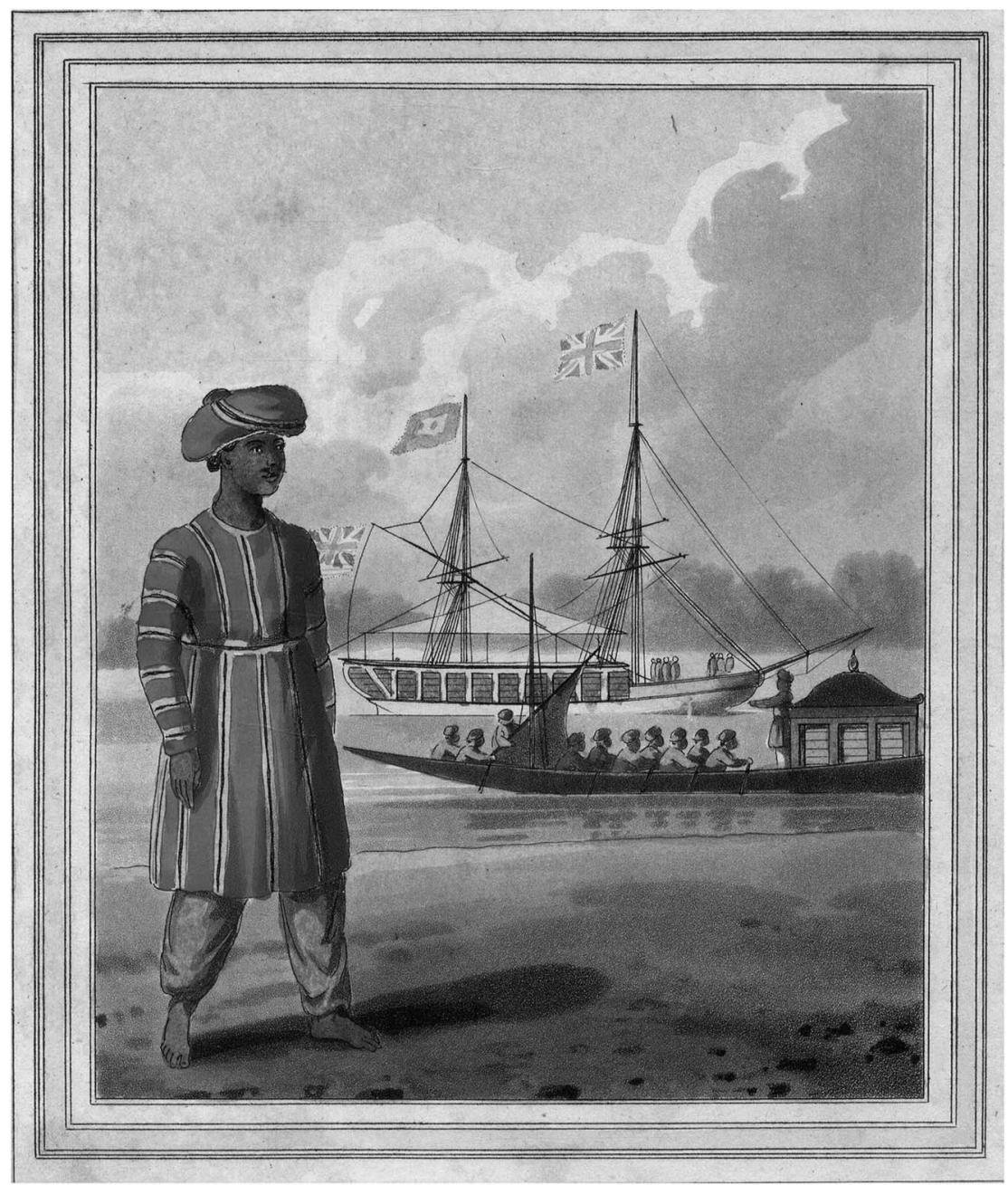

Figure I. A state boat establishment dandy.

The European in India, Plate XII.

needs to be seen in the light of how the work was done and the challenges that were faced by both employers and employees.

\section{WORLD OF WORK: HARD-WORKING DANDIES}

Work involved twin aspects of skill and physical exertion. For manjhees, being the master and thus in a privileged position, the latter was not of such importance. The golleabs, as observed in the above passage, combined both skill and physical faculties. For dandies, it was their physical 


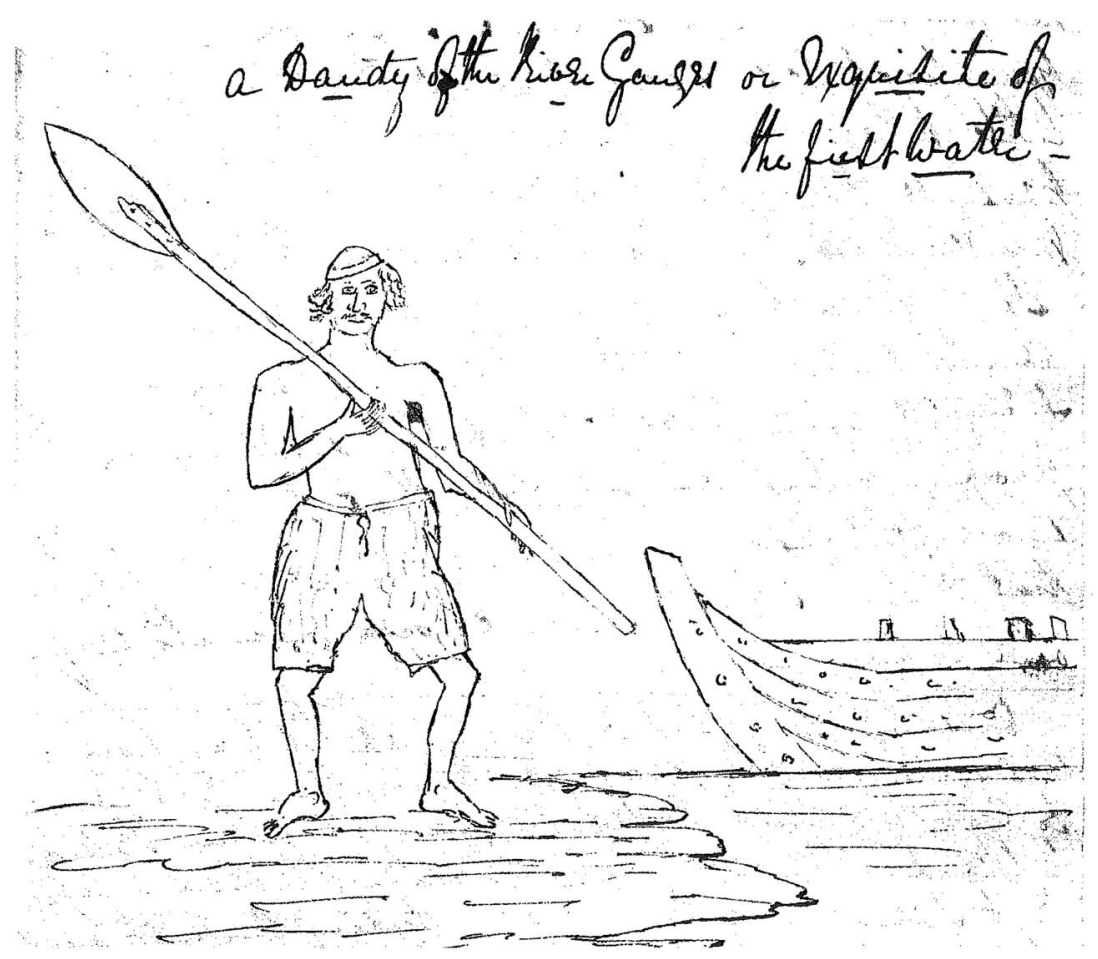

Figure 2. A dandy working on the river Ganges.

Francis James Hawkins, Diaries and Letters, Mss. Eur. B 365/4 ff. 2. (C) The British Library Board, EUR B $365 f_{2-4}$. Used with permission.

labour that was most frequently referred to. For the journey between Calcutta and Allahabad, which normally took three months, these dandies, owing to unfavourable stream currents, had often to track boats from the shore. Neck deep in water, pulling the shore ropes and frequently forced to swim with ropes tied to their waist, their work left an imprint on their bodies. Bishop Heber had observed:

Our own men, though all in the prime of youth, well fed, and with figures such as statuary might delight to model after, themselves show too many symptoms of the ill-effects occasioned by their constant vicissitudes of water, sun, and toil. The backs and skin of many of them were scaly, as if with leprosy, and they spoke of this complaint as a frequent consequence of their way of life $[\ldots] .57$

57. Reginald Heber, Narrative of a Journey through the Upper Provinces of India from Calcutta to Bombay, I824-25 (London, I 828; repr. New Delhi, I993), I, p. I 20. For the hard toil and skill of dandies as well as their knowledge of waterways, see also Henry T. Bernstein, Steamboats on the Ganges: An Exploration in the History of India's Modernization through 


\section{Or consider the account given by Charles Ramus Forrest:}

These are a hardy race of beings, wear but little clothing, and though exposed in towing the boat for the whole day to a burning sun, and frequently up to the middle in water, their heads are not only without any turban or covering, but literally shaven quite bare. Their skull, probably from constant exposure, becomes hard and thick enough to resist the rays of the sun thus pouring on their naked scones. ${ }^{58}$

The labour and skill involved in rowing depended on the nature of the merchandise, boats, and oars. For instance, rowing a flat-bottomed merchandise boat (patella) required ten to twelve men working in a standing position with bamboo oars almost eighteen feet in length with a broad round blade at the end. ${ }^{59}$ In contrast, many a variety of pleasure boats required dandies to be seated and to use paddles. Apart from rowing and tracking, mooring the boat safely on a soft sandbank was also physically demanding. An anonymous traveller thus described how:

The operation of securing the boats to the shore which is a work of some time and labour and is performed by driving heavy piles into the earth both before and after the vessel so as to moor Her securely to them against the force of the water, took up about half an hour. ${ }^{60}$

This physical hard work was aggravated by the changing and difficult weather conditions. Unlike dak (mail-delivery) travelling, which was frequently done during the night, river travel was restricted to daytime because "the shifting nature of the land banks and violent currents renders it impossible to go on in the dark". ${ }^{61}$ On the basis of hard work and "consummate drudgery", Williamson compared the dandies' hard life to that of a scavenger's carthorse, symbolizing the equation of human to animal power. Taking into account this laborious employment, aggravated

Science and Technology (Calcutta, 1960), pp. 16-17. For tracking a boat with a combined crew of three yet yielding no results, see Raleigh, Mss. Eur. D 786, pp. 7, I 4.

58. Charles Ramus Forrest, A Picturesque Tour along the River Ganges and Jumna in India [...] (London, I 824), p. I 24. The examples can be multiplied. John Luard described dandies in the following manner: they "work laboriously from sunrise to sunset, frequently in the water for hours, up to their middles, shoving with their backs the boats over sand banks"; John Luard, A Series of Views in India [...] (London, I833), Part II, text accompanying "A Budgerow", p. I037. Lowrie, a missionary, described them as "a peaceful, hard-working, and obliging race; [who] are compelled to live nearly at the lowest point of human subsistence"; Lowrie, Travels in North India, p. 92; on the toil of tracking and his fear of drowning, see pp. 68, 99-100.

59. Hardgrave, Boats of Bengal, p. 88.

60. Anon., Journal of a Voyage of Exploration of the River Ganges Upstream to Patna, 28 July-30 August I 82 I, Mss. Eur. E 27I, p. I 2. Strong winds weakened the moorings; in such a situation, the boatmen's alacrity, even at midnight, was indispensable to save the boat from being either carried away or sunk; Lowrie, Travels in North India, p. 83.

61. Raleigh, Mss. Eur. D 786, p. 3. 
by uncertain and unfavourable weather, he invited his readers to empathize with the bodily exertion of this class:

Imagine the effects, even upon the most hardy constitution, of exposure to all weathers; at one moment under a burning sun, or numbed by a cold northerly blast; by turns on board, or at the track rope; moving at a slow pace against a rapid current; and wading, without the smallest hesitations, through a million of puddles, often up to the neck, or even obliged to swim: the footing perhaps rugged, or along a heavy sand, or a deep mud; and the path lying through briars, bordering steep precipices! All this the dandy undergoes for the small wages $[\ldots]^{62}$

There are numerous instances recorded in the administrative papers and travel writings of the period to suggest that the loss of men and material was not an infrequent occurrence. In spite of the high romanticization of landscape and river journey, the risk involved was evident from frequent textual and visual representations of squalls and thunder storms on the river Ganga. ${ }^{63}$ Raleigh, who accompanied Lord Amherst's royal entourage as a surgeon, reported frequent sinking of boats and supplies, and the drowning of native soldiers. While describing the drowning of a soldier during a squall, he compared the Ganga to a sea and presented the difficulties of navigation in the following manner: "although it may appear absurd to talk of 'sea' in the river, a squall on the Ganges in flat-bottomed, unwieldy pinnaces and budgerows is no joke, and a far more dangerous position than in a gale at sea in a good tight ship". ${ }^{64}$

The rainy season had a favourable wind blowing from the south-east but was nevertheless hazardous because of rains and squalls. ${ }^{65}$ On the other hand, the hot season, when the water level was low, made tracking inevitable. For certain stretches of the river, such as that between Berhampore and Murshidabad, the river was low at all seasons. Here, tracking took almost seven hours for a distance of seven miles, which by dak travelling took about one hour. ${ }^{66}$ The sand blowing off the banks also

\section{Williamson, The East India Vade-Mecum, I, p. 286.}

63. Henry Salt's 1803 drawing, reproduced below, is illustrative of this; the British Library online gallery has titled it "Scene on the Ganges near Sahibgunge". In Mildred Archer, British Drawings in the India Office Library (London, I969), II, Plate 67, it is titled "A Storm on the Ganges, Near Sahibgunge". On the back of the painting itself, however, Salt had written "Ganges. Where Boatmen were nearly drowned”. The incident he referred to took place during Lord Valentia's travels, in which two men, while trying to row the boat, were nearly drowned by the currents; http://www.bl.uk/onlinegallery/onlineex/apac/other/orgwdz000000I04u00000000.html, accessed 25 November 2013. Rains and waves wetting the interior of the cabin were often reported. See Anon., Journal of a Voyage of Exploration of the River Ganges, pp. 67, 87-88; Hawkins, Mss. Eur. B $365 / 4$ ff. I-28, pp. 7-8.

64. Raleigh, Mss. Eur. D 786, p. 6.

65. A sudden spring tidal rush, locally called ban in Bengali, in which the water rose up to five feet on the shore, was deeply feared; Hardgrave, Boats of Bengal, pp. 39-41.

66. Deane, A Tour through the Upper Provinces of Hindostan, p. 275. 


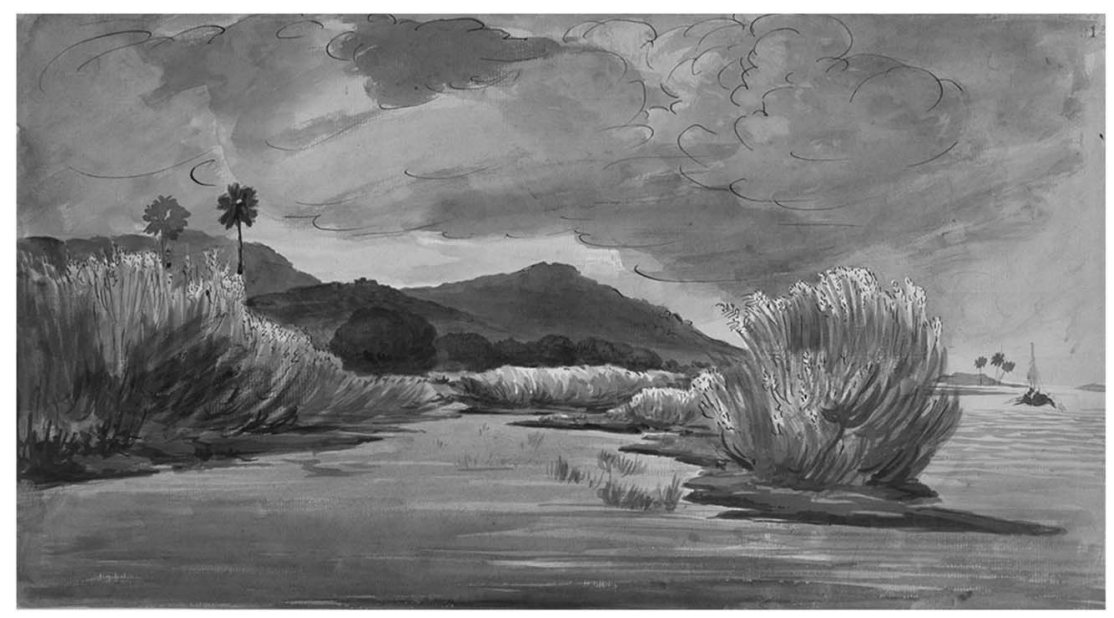

Figure 3. Henry Salt, "Ganges. Where Boatmen were nearly drowned".

http://wwrw.bl.uk/onlinegallery/onlineex/apac/other/largeimage65774.html; (C) The British Library Board, WD I04. Used with permission.

made the work difficult. ${ }^{67}$ Kaal-Baisaki (disaster of May), as it is known locally in the region, or the north-westerly winds, as they were called by Europeans, was a feature of the months between April and June. These winds were particularly disastrous because of their suddenness and strength. ${ }^{68}$ Frederick Augustus Barnard Glover, a Bengal civil servant living in a town situated on the banks of the Ganga, explained to his wife the impossibility for those who have not been to India to imagine the difference in the streams during the hot and rainy seasons. ${ }^{69}$

Although a lot of accounts did present the physical exertion and hard work of dandies in a sympathetic way, there is, at times, a lurking hint at a cultural understanding of their work. One of them was the disapproving tone in which travellers described dandies' antipathy towards each other in times of distress. They were accused of being cold and indifferent towards their fellows' misery, particularly when it came to saving those drowning. ${ }^{70}$ Their skill was also questioned; surprisingly, after giving a

67. The anonymous traveller mentioned the difficulty this presented to the travellers, but the same can also be said for the boatmen; Anon., Journal of a Voyage of Exploration of the River Ganges, p. 76 .

68. Hardgrave, Boats of Bengal, p. I4.

69. Frederick A.B. Glover, Four Letters from Frederick Augustus Barnard Glover, Mss. Eur B 371, p. 6.

70. On the wreckage eliciting no excitement, see Anon., Journal of a Voyage of Exploration of the River Ganges, pp. 84-85; on the indifference of dandies to saving their fellows from drowning, see Raleigh, Mss. Eur. D 786, p. 6. 


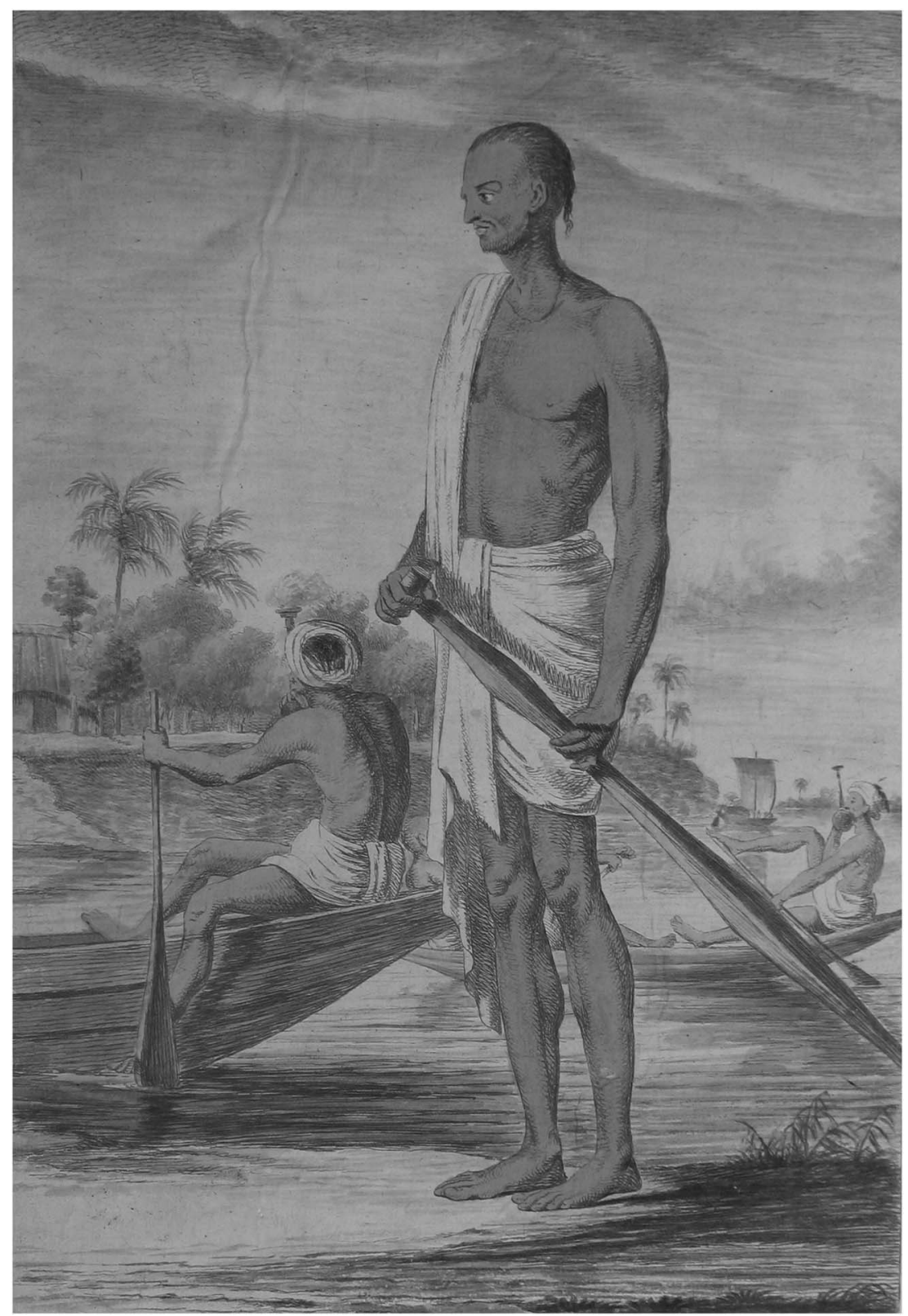

Figure 4. "Dandi, Boatman".

Etching from Balthazar Solvyns, A Collection of Two Hundred and Fifty Coloured Etchings (Calcutta, I799). Reproduced, with permission, from the collection of Robert L. Hardgrave, Jr. For a discussion of the Dandy, see Hardgrave, A Portrait of the Hindus: Balthazar Solvyns and the European Image of India: I760-I 824 (New York [etc.], 2004), pp. 2I 8-219. 
long vivid account of torrents and rain, the wreckage of boats, and almost facing death, Lowrie caustically remarked that boatmen were unskilful and reckless. ${ }^{7 \mathrm{I}}$ Another was the practice of hookah smoking, which Solvyns pictorially depicted (Figure 4) as the chief characteristic of dandies (both dandies in the background are smoking hookah).

Ahuja has argued that the dominant strand of colonial culturalist representations depicted workers in Madras city as lazy and in need of "restraint, authority and even compulsion to be roused from apathy" ${ }^{2}$ Without saying this in so many words, his account shows how cultural traits legitimized colonial interventions in areas of wage fixation and labour regulation. Surely, for boatmen in eastern India this was not the case. In spite of the cultural hues of secondary importance that coloured some accounts, a majority of them boldly took note of the hard work that dandies performed. It is thus pertinent to ask if plausible explanations of these cultural readings can be offered which stem from within the work process that involved rowing, tracking, and mooring. Do indirect references to skill explain direct observations on work practices, including culturally situated representations?

A range of commentators described dandies as amphibious. Lowrie noted that they were of "an almost amphibious race", not to be drowned easily. ${ }^{73}$ Said in the context of a personal fear that he alone would drown, this characterization should be read as a description of the relationship between dandies' skill and their working conditions. Constant storms and rains that led to the frequent wreckage of boats and loss of property may have honed the skill but also plausibly eroded the sense of loss or fear. For some Europeans, the superior level of dandies' skill in dealing with difficult working conditions thus coalesced into a cultural reading of them as indifferent to their own lot.

Contract, bad weather, difficult and uncertain navigable conditions, and the physically demanding nature of work informed the working conditions of boatmen, particularly for dandies. There was, nevertheless, one more factor. Correspondence from this period is very much concerned with preventing delays. Delays, which otherwise appear to, and did in fact, occur due to factors producing uncertainties, can also be understood as depicting anxiety arising from the structured relationship between

71. Lowrie, Travels in North India, p. 73. Perhaps, being a missionary, he was compelled to acknowledge the saving grace of the Lord rather than the efficient rowing hands of his boatmen; see pp. $73-74,87$.

72. Ahuja, "Origins", p. 170.

73. Lowrie, Travels in North India, pp. 68-69. Another missionary reported a native boat crashing into his own and getting completely splintered. He noted that boatmen "swam like ducks, and none were lost"; Zebina Flavius Griffin, India and Daily Life in Bengal (Buffalo, NY, i896), p. I Iо. 
time, money, and distance. This relationship upon which the work of dandies was judged was related to the regime of contract that existed between the government and Company individuals. Officials of different ranks, ranging from a colonel to a cadet, received a fixed boat allowance. ${ }^{74}$ This was accompanied by a table of distances from one station to another calculated in terms of months. The difficulty in procuring boats was not treated as constituting a delay.

What we have here is a strict if not fixed understanding of travel time. The fixed monetary allowances paid to Company employees must have enforced the pressure on manjhees and dandies to finish their work in the time stipulated. This also explains why the thika system was used. According to Williamson, thika hire ensured that manjhees would finish their work as speedily as possible. For this, they would hire a good crew of dandies. In contrast, he claimed that under the monthly contract system "there will be no end to excuses, delays, and evasions: the dandies will generally be wanting in number, and their quality be very indifferent" ${ }^{75}$

A critical appraisal of the category of delay reveals the interlinked economic conditions which were not directly imposed on boatmen. For, even if we accept Williamson's observation, there could only be so much delay intentionally engineered by boatmen and contested as permissible and negotiable within the broader framework set by the officials' monetary allowances and the time stipulated for arriving at the specified destination. The category of "delay" was premised upon the idea that there was a standard ideal speed that needed to be adhered to. In cases of unspecified rates, ten miles against the current and fourteen with was taken as standard. ${ }^{76}$ The officials themselves wanted to finish their journeys in time, as delays were not compensated. One can, therefore, argue that the cultural idiom of laziness which the natives were often imputed with, or the wilful act of resistance designed to intentionally delay, had its roots in part in the nature of the fixed allowances that European officials received from the Company.

\section{"MUTINOUS" DANDIES}

Hard work as a "way of life", as Heber described it, ${ }^{77}$ was mediated through contract, advance payment, time-money relationships, and difficult work environments. The question of delay created a suspicious relationship between the traveller and the boatmen. However, long periods of travelling

74. See HP, Consultation, 7 June I773, nos. 29-30; Williamson, The East India Vade-Mecum, II, pp. 369-370. Unless indicated, the following account is based on these two sources.

75. Williamson, The East India Vade-Mecum, II, p. 374.

76. Ibid., p. 370.

77. Hawkins described it as "tedious work"; Mss. Eur. B 365/4 ff. I-28, p. 2. 
made Europeans dependent on these dandies for knowing places and gathering general information about the country.

These constellations are nonetheless important in understanding the context in which dandies were called "mutinous". In other words, the extent to which dandies would have adopted a "mutinous" attitude obviously hinged upon aspects of wage and payment but it was also influenced by the realization and exploitation of the extent to which they could push their bargaining power in the zone of asymmetrical proximity. Many travellers carried guidebooks, grammar books, and other "scientific equipment", such as telescopes, but informal conversational exchange was a regular feature on the boat. Heber was informed about a variety of matters by his boatmen. ${ }^{78}$ In times of crises, for instance during Chait Singh's rebellion in Benares in $178 \mathrm{I}$, boatmen became a major source of information and intelligence. ${ }^{79}$ Mobility allowed them to possess not only specific skills related to navigation but also information deemed important for political control. Due to this, they also became victims of political rivalry. ${ }^{80}$

When his dandies refused to take him further without an advance payment, William Parry Okeden labelled it a "boatmen mutiny". He was eventually forced to comply with their wishes. ${ }^{8 \mathrm{I}}$ This was not an isolated case; other travellers also mentioned mutinous moments, which were sometimes avoided by accepting dandies' demands and at other times by using force or the threat of force. The fact that delays and mutinous conditions could also be caused by bad weather did not go unnoticed; the anonymous traveller and his friends had reluctantly to accept the decision of the majority of manjbees to halt their journey due to bad weather. ${ }^{82}$ However, in most colonial accounts the alleged wilful delays act as a precursor to mutiny by dandies, which would usually be based upon a demand for advance payment.

An interesting "mutinous" situation developed on the boat of the anonymous traveller's friend. He had prohibited the crew from preparing their morning meal in his presence. The reason was the noise and smoke (including smoke coming from the hookah). Usually, by nine o'clock in the morning he would join his friend and leave the crew to do their

\footnotetext{
78. Heber, Narrative of a Journey through the Upper Provinces of India, pp. 105, 107.

79. On matters related to revenue, the Raja of Benares had militarily challenged the authority of the EIC. His rebellion can be described as one of the most serious challenges the EIC faced in the late eighteenth century. Boatmen again became strategically important during the I857 "Mutiny".

80. Reportedly, dandies of the governor-general's fleet were captured and either drowned or were killed; James, Selections from the Correspondence of the Revenue Chief of Bihar, pp. 79-80.

81. Diary and Sporting Journal of William Parry Okeden, India, I82I-4I, Mss. Eur. A 210 , p. I6.

82. Anon., Journal of a Voyage of Exploration of the River Ganges, p. 37.
} 
chores. This order, however, was allegedly often disobeyed and hence the officer threatened to break all the cooking pots of the dandies. The latter then threatened to desert; the burkandazes (guards, usually with matchlocks) were called in to arrest the "mutineers" in case they persisted with their threat. ${ }^{83}$ Thus, amidst the informal exchange between travelling Europeans and rowing dandies, a zone of mutual suspicion and dependence existed. On the threat of desertion, the traveller remarked that "[ $\mathrm{t}]$ his was not to be allowed of course, either for their sakes or ours" ${ }^{84}$

Violence and threats were often resorted to in order to reinstate control. It is thus no surprise to see Heber commenting that "one fertile reason of boatmen's desertion was the ill conduct of Europeans, who often stimulated them [dandies] to do things which, in their weak and clumsy boats, were really dangerous, and against all law or right, beat them when they refused or hesitated" ${ }^{85}$ Insistence by European masters on doing something that potentially threatened the boats and the dandies' means of livelihood, as well as the prohibition of certain practices such as preparing morning meals, thus constituted two sides of the volatile relationship forged between dandies and their masters on the space of the boat. Keeping such mutual dependence in mind, Williamson advised travellers to strike a balance of resolution and conciliation that would realize the desired effect without coming across as brutal and harsh. ${ }^{86}$ Lowrie's description of his conduct based on "mild firmness" comes close to what Williamson had suggested. ${ }^{87}$

This firm but mild temperament was required not only to reaffirm authority but also to secure personal comfort. In a colonial situation, a public display of authority always needed to be balanced with private comfort, especially during long sojourns and journeys. Deane warned her readers: "It is always desirable to keep him [manjhee] in good humour, by attending a little to his advice, as on his depends in a great measure both your expedition and comfort of the voyage." ${ }^{88}$ It must, however, be said that for many newcomers, officials, and Europeans living in India, river journeys became pleasant and bearable owing to constant visits to and from friends and acquaintances residing in places along the Ganga. The cultural "zone of contact" that existed between them and the boatmen was sprinkled all around with "zones of comfort" forged by meeting dispersed members of the British community. A slightly different feature is observable in missionary writings though; surrounded by "strange and

83. Ibid., p. $3^{8}$.

84. Ibid.

85. Heber, Narrative of a Journey through the Upper Provinces of India, p. 2 I I.

86. Williamson, The East India Vade-Mecum, II, p. 375.

87. Lowrie, Travels in North India, p. 64.

88. Deane, A Tour through the Upper Provinces of Hindostan, p. 273. 
heathen people", they saw the journey itself as an opportunity to reassert their faith in missionary activities. ${ }^{89}$

Partly because of this sense of dependence and anxiety, but also because of the fact that "travel by the river was literally confined to the river", ${ }^{\circ}$ where the only long association with the natives was through the group of boatmen (and servants), there were moments of jocular exchange. When the wind blew off Raleigh's hat, one of the dandies made to catch it and fell overboard with the hat in his hand. Raleigh commented, "[h]owever, he was soon up again like a duck. These men are perfectly amphibious, and would as soon as be in the water as out." ${ }^{11}$ Again, when he claimed to have called the bluff of a gunpowder seller who falsely tried to impress Raleigh, the latter gave him a thump on his head and the dandies who joined "in the joke, pitched my friend [the seller] overboard, to the great amusement of the people on the shore". ${ }^{22}$ Sometimes, even physical contact was unavoidable. While traversing the landscape of Bengal, the missionary Griffins couple had to sit on the hands of the boatmen to be ferried across to dry land. They noted, "We do not so much object to putting our arms around the neck of each of these men, but sometimes the ladies would rather be excused. But it must be done, all the same."93 The whole group consisting of dandies, manjhees, and servants were a constant source of information, amusement, and chat. Sometimes, they also asked their British masters about their lives and friends back in Britain. ${ }^{94}$

It is important to recognize that while work in its stricter economic sense was premised upon the notion of contracts and wages, the experience of being at work did not necessarily depend on these factors alone. Anxiety and amusement were part of the same relationship forged on the space of the boat, as were the elements of authority and desertion. A lot of Europeans talked about dandies in functional terms of work, but they also shared their routinized lives on the boat and ashore. For them, the dandy's curry was perhaps avoidable but not untouchable. In any analysis of the relationship between travelling Europeans and their rowing dandies, the shared space of the boat has to be taken into account because it allows us to understand the nature of work within the context of worksites, which were precisely the river, the banks and the boat. This relationship between work and worksite is also important in understanding the moments of solidarities and differentiations formed among the boatmen.

89. Lowrie, Travels in North India, p. 61. For a more direct observation on the missionary benefits of boat journeys, see pp. 105, 108-109.

90. Deane, A Tour through the Upper Provinces of Hindostan, p. 226.

91. Raleigh, Mss. Eur. D 786, p. I0.

92. Ibid., p. I I.

93. Griffin, India and Daily Life in Bengal, p. 4I.

94. Hawkins, Mss. Eur. B 365/4 ff. I-28, pp. 7-8. 
When Lowrie hired his budgerow and luggage/cook boat from the agency at Calcutta, little did he know that he would soon be enforcing his "mild firmness". The boatmen of the budgerow insisted on cooking on the boat, which he firmly denied but allowed them to do on the cook boat. This, nonetheless, was resisted by the boatmen of the latter. Lowrie felt compelled to explain this resistance by pointing to caste restrictions, but soon he referred to it as a "matter of convenience", which indeed seems to have been the case. Finally, three cooking places were set up on the cook boat: one each for Lowrie and his servants, the crew of the budgerow, and the boatmen of the cook boat.95

\section{“THIEVISH” DANDIES: WORK AND REGULATION}

While introducing the dandy serving in the governor-general's boat establishment (Figure I), the author noted,

The person exhibited in this Plate must not be viewed as the ordinary Dandy, or boatman, employed in the vessels trading throughout the country; these being generally poor naked wretches, whose avocation is, perhaps, the most laborious of any yet known, and whose depravity and thievish habits are absolutely proverbial. ${ }^{6}$

Williamson also warned his readers of the manjhees' profit-making tactics. Newcomers, in particular, were asked to remain vigilant of the boatmen. But this was said in the context of occupational privilege (or extortion) involved in by helping the newcomers; otherwise, it would be erroneous to read a culturally essentializing tone in this characterization. Williamson himself made it clear that,

It would not be just to infer from [...] the readiness with which the boatmen avail themselves of the necessities of persons desirous to leave a ship, that they are particularly covetous, or prone to imposition: we need only look at home, where we shall find that no mercy is shewn to such unfortunate persons as become the prey of our watermen, along the whole extent of our coast. ${ }^{97}$

Rather than invoking any independent ideological bases of civilizational inferiority (such as Asiatic despotism), Williamson's characterization of physical appearance and morality is inseparable from the context of work. The outer physical appearance, which was full of ringworms, itch, and herpetic eruptions all over the back, chest, and arms, made a Bengal dandy the most disgusting mortal. But the hard work and modest wages that explained this physicality also explained why "the European must blame

95. Lowrie, Travels in North India, p. 64.

96. The European in India, text accompanying Plate XII.

97. Williamson, The East India Vade-Mecum, I, p. I48. 
himself, should his valuables be missing in consequence of an ill-placed confidence, or of neglect in regard to securing his property, so far as may be practicable"..$^{8}$ By this understanding, a thievish nature arose out of an impoverished condition. For manjhees, who were relatively better off, mobility became the factor that encouraged "depravity". The boats carrying colonial officials were seldom checked at river outposts. Manjhees allegedly used this immunity to carry out illicit trade. The space of the boat under the deck (from the veranda to the stern), which he allegedly zealously guarded as his privilege, was used for storing commodities such as salt and opium. ${ }^{99}$

Moral depravation of boatmen developing due to poverty or privilege conditioned by work was often reported. However, it was the constant evidence of their mutinous character exhibited either in a refusal to row or in simply "absconding" that led to stringent policing measures. It was already noted how burkandazes were summoned to use the threat of arrest. In such cases, it was advisable for the traveller to report the matter to the police, who would place a burkandaz or a peon (an attendant, usually without a matchlock) on the boat at the expense of the manjbee. ${ }^{\text {100 }}$ Meanwhile, public ferries and other boats gradually came under regulative scrutiny. Under Regulation XIX of I 8 I 6 , collectors (district civil officials) had to report on the number of public ferries, tolls levied, and the number and size of boats maintained at the various ghats. ${ }^{\text {IOI }}$ The private keepers of boats and boatmen were also made accountable; for instance, indigo planters had to submit statements giving the number and size of boats employed at their factories, together with the names of the manjbees. ${ }^{102}$ Under the same regulation, collectors were also directed to fix the wages of the boatmen. ${ }^{103}$ Regulation VI of I8 19 , however, rescinded the parts dealing with the management of public ferries. ${ }^{104}$ The number of public ferries was reduced, but most importantly they were now put under the supervision of magistrates (district police officials).

The stated objectives were to strengthen policing, promote the safety of travellers, and facilitate the conveyance of troops. In all these, manjhees became the centre of regulation. In the event of misconduct, the magistrates

98. Ibid., p. 287. For his related views see also pp. I48-1 52, 286-288.

99. Williamson, The East India Vade-Mecum, II, pp. 377-380. Lowrie reported an incident when a manjhee of another boat had come to him selling European goods which consisted of "a box of old Windsor soap and a cracked bottle of arrow root"; Lowrie, Travels in North India, p. 91.

Iо0. Williamson, The East India Vade-Mecum, II, pp. 374-375.

ıог. Pranab Chandra Roy Chaudhury, Muzaffarpur Old Records (Patna, 1959), p. 304.

102. Ibid., p. 309.

I03. Ibid., p. 306.

104. "Bengal Regulation VI of I 8 19", in Papers Relating to East India Affairs: viz. Regulations passed by the Governments of Bengal, Fort St George, and Bombay, in the Year I819 (London, I82 I), pp. I9-22. 
had the power to replace them. Manjhees were also obliged to ferry troops free of charge (with their baggage and stores), policemen, and other native government officers travelling on public duty. In cases of drowning and accidents, if it could be proved that the reason was the overloading or the bad condition of the boat, manjhees could be imprisoned for a period not exceeding six months or charged a fine of Rs 200 .

The idea of promoting free commercial intercourse was aired by professing non-interference in the management of private ferries, but, once again, magistrates could interfere if matters related to the "general maintenance of the police" and the "safety of passengers and property". ${ }^{\circ}$ s The discussion on the conveyance of troops should be recalled here. While Regulation XI of I 806 tried to protect coolies and boatmen available at the river ghats from the excesses of travelling military men, it also made those who were part of the fleet accountable for carrying out their work. Manjbees "were required to deliver a list of names and places of their dandies, and sign the agreement", which read:

I will not permit or induce any of the dandies of my boat to abscond during the voyage under the penalty of forfeiting the sum of $[\ldots]$ payable to me at (the destination), and that in the event of the Hon'ble Company being put to any expense for the hire of dandies in consequence of any of my people absconding my boats shall be liable to confiscation. ${ }^{\text {I06 }}$

Regulation VII of I8I9 has been identified as one of the early ones absorbing the essence of master and servant law that made workmen criminally accountable for breach of contract. ${ }^{107}$ In such cases, workmen, if found guilty, faced one month's imprisonment (with the possibility of two further months in prison), whereas masters, if guilty, had only to compensate through the payment of wages and arrears. This regulation, it should be noted, was theoretically premised upon two parties voluntarily entering into a contract. Boatmen must have come under the ambit of this regulation as the practice of private travelling and also transporting troops and merchandise was based on contracts. However, for boatmen the two aspects of regulation of work, the payment of damages due to desertion and imprisonment, predated the 18 I9 Regulation. ${ }^{\text {108 }}$

The strength of these regulations definitely derived from the notion of contract and its breach, but the framing of the regulations was itself part

I05. Ibid., p. $2 \mathrm{I}$.

I06. "Rules and Regulations for the Transport of Troops", Board of Control, CLXXXI, I 806-07, F/4/191, 4260, Asia, Pacific and Africa Collections, British Library.

107. Mohapatra, "From Contract to Status?"; "Bengal Regulation VII of I 819", pp. 23-24.

I08. There are examples from the period before this regulation was passed that show dandies put to hard labour on road construction as part of penal punishment; "Letter from R. Graham, Acting Collector of Tirhoot to Charles Buller, Sub-Secretary to the Board of Revenue", 30 May I800, in Chaudhury, Muzaffarpur Old Records, p. 176. 
of the broader political context in which the early colonial state operated. This context was one of state consolidation of power through the efficient movement of troops. The ideological context was also present; this related to providing safe travelling conditions for individuals and troops, but also to protecting the workforce against any sort of highhandedness. Work enforcement and protection as mediated through the authority of the police had two interrelated aspects. First, police authority was used to enforce the contractual arrangement, leading to the possibility of the workforce being criminalized; second, the police were very much part of the process through which contractual arrangements were finalized.

According to the clauses of Regulation XI of I 806, the police officers were not only supposed to enforce carefully the just compensation for using bearers, coolies, boatmen, carts, and bullocks but also "authorized to adjust the rate of hire $[\ldots]$ as well as demand that the whole or a part, according to the circumstances of the case, be paid in advance". ${ }^{\text {I09 }}$ The advance system was used and explained differently by the parties concerned. For travellers like Deane, advance payment emboldened boatmen to press their demands and hence made them rebellious; for the state, to make sure that boatmen were paid due advances was part of the protective shades of regulations; and for boatmen themselves, advance was a way to provide for their families when they were away at work. However, the part payment of wages as advance that formalized a contract was also, as Mohapatra has argued, an instrument "to tie down workers" by limiting their options of free exit. ${ }^{\text {I }}$ (

So far, I have looked at work and its structuring constituents to understand the regulative policies of the colonial state. The period of this study was nonetheless also marked by frequent incidences of crime, in particular those committed during travel. A lot has been written on the theme of thugee and highway crimes, but the Ganga (being the highway connecting eastern and northern India) was also an active and a rather difficult to control scene of crime. ${ }^{\text {II }}$ Like other peripatetic groups, such as banjaras and gosains, boatmen came under colonial suspicion and scrutiny, at least for being collaborators if not direct perpetrators. The state envisioned the involvement of dandies in two ways: first, directly committing river dacoities, second, aiding the dacoits and criminals. In addition, criminals might disguise as dandies, making all of them, in the eyes of the authorities, suspicious. ${ }^{\mathrm{II} 2}$ An extensive system of river patrolling

109. "Bengal Regulation XI of I 806", in Wigley, The Eastern Bengal and Assam Code, p. 92. I Io. Mohapatra, "From Contract to Status?", pp. I 20-I II.

I I I. As late as the early twentieth century, it was estimated that about 50 to 75 per cent of river crime went unreported to the police; F.C. Daly, Manual of Criminal Classes Operating in Bengal (Calcutta, 1916), p. 88.

I I2. On criminals disguising themselves as either passengers or dandies, see Datta, Selections from the Judicial Records, p. 296. 
was organized in the all-important riverine districts of Bihar and Bengal. ${ }^{113}$ To help combat crime, magistrates were given additional powers to search boats.

From the mid-nineteenth century on, the nexus between colonial ethnography (primarily caste-based) and the understanding of the occupational history of different professional groups reified into the notion of hereditary criminality. The river dacoities, which in Bengal became a major subject attracting recurrent administrative attention, continued throughout the nineteenth century. ${ }^{\mathrm{II}} 4$ This aspect lies outside the purview of this article, but it must be pointed out that by 1872 the Mallah caste, a prominent boatmen caste, had been added to the list of "criminal tribes". ${ }^{\text {Is }}$ It was, nevertheless, a long-drawn-out process. Even as the police understood it, the Mallah caste was, until late, seen as a professional-occupational category comprising a number of sub-castes working on rivers as traders, boatmen, or fishermen. It was only in I9I 4 that some of them coming from the different districts of the United Provinces were declared to be criminal tribes (under the Criminal Tribes Act of I87I, CTA). ${ }^{\text {II }}$ Furthermore, as Smita Tewari Jassal's study shows, Mallahs were classified under Class B of the CTA, meaning that although they were "criminals" they had recently settled down to agriculture, in contrast to tribes classified under Class $\mathrm{C}$, which required resettlement and transportation. ${ }^{117}$ The upshot of this argument is that the occupational diversification, including settlement in agriculture, had taken place before the I87I census and the passing of the CTA. I have elsewhere explored the implications of this diversification from being mobile to settled, ${ }^{118}$ but the factor of the regulation of boatmen was something conspicuous throughout the period. A set of rules for river navigation passed in I 867 required each boatman to "provide details, such as caste, patrilineal descent, place of residence and the "length of the river under his pilotage"'. II

The caste composition of criminals in colonial accounts was not something novel to the second half of the nineteenth century. Nor, as

II3. I have covered this theme in detail elsewhere; see Nitin Sinha, Communication and Colonialism in Eastern India: Bihar, I760s-I880s (London [etc.], 20I 2), pp. I44-I 49.

I 14. For instance, see Home Police, A, January i868, nos I4-16, National Archives of India, New Delhi; Arun Mukherjee, "Crime and Criminals in Nineteenth Century Bengal (I86I-I904)", Indian Economic and Social History Review, 2I (1984), pp. I53-I83, I64-I66.

II 5. Assa Doron, Caste, Occupation and Politics on the Ganges: Passages of Resistance (Farnham, 2008), p. 30.

I 16. Daly, Manual of Criminal Classes, pp. 87-88, 93.

I 17. Smita Tewari Jassal, "Caste and the Colonial State: Mallahs in the Census", Contributions to Indian Sociology, 35 (2001), pp. 319-354, 340-342.

I I 8. Sinha, Communication and Colonialism, I91-192.

I I9. Doron, Caste, Occupation and Politics, p. 39. 
Arun Mukherjee has argued, was the involvement of the up-country Mallahs coming into Bengal from the North-Western Provinces (NWP) and Bihar a new feature. ${ }^{20}$ However, as far as caste-based description in ascertaining the role of boatmen was concerned, a shift is discernible from the earlier period. Barring few instances, the late eighteenth- and early nineteenth-century accounts usually use the work-based categories of manjhees, golleabs, and dandies. In the sources used in this article, only one reference each to Mallahs of the NWP and Kaibarta of Bengal has been found. ${ }^{\text {I2I }}$ Whether this signifies a radical move from a work-based to a caste-based understanding of Indian society remains a question for further research, but these sources provide an interesting entry point to look at work, caste, and ritual purity together.

The above point relates to accounts of the dietary practices of boatmen. In late nineteenth-century caste-based accounts, such as that of William Crooke, Mallahs were associated with a ritually inferior position in the caste hierarchy; this was shown by giving details of their "polluting" dietary habits. Apart from fish and meat, they allegedly also ate rats, tortoises, crocodiles, and practised excessive alcoholic consumption. ${ }^{22}$ However, looking at descriptions of cooking practices as reported by several travellers of the earlier period, no trace of the dandies" "derogatory" and "polluting" practices can be found. There are two conflicting accounts of how they prepared their food. According to one, boatmen reportedly did not cook their food on board; they ate only parched rice while on board and prepared their dinner ashore in the evening after mooring their boats. This practice was so strictly observed that at times, when rain did not permit them to prepare their dinner, they did not eat at all. This was true for the "Hindu" members of the crew; the Muslims reportedly ate on board. ${ }^{\mathrm{I} 3}$ The second view suggests that they did prepare their food on board, and this was in fact, at times, the reason behind the conflict between European travellers and boatmen. ${ }^{124}$ Whatever might

I 20. Mukherjee, "Crime and Criminals", p. I65. On the use of caste to understand criminality and on up-country mobile gangs in the earlier period see Sinha, "Mobility, Control and Criminality", pp. 22-25.

I 2 I. In one of the preliminary studies on fisheries, Peter Reeves has argued that there was not much of a difference between Kaibarta and Mallah castes in the two provinces; Peter Reeves, "Regional Diversity in South Asian Inland Fisheries: Colonial Bengal and Uttar Pradesh Compared", South Asia: Journal of South Asian Studies, 25 (2002), pp. I 2 I-I 35 , I 27.

I22. Doron, Caste, Occupation and Politics, pp. 32-33.

I 23. Caleb Wright and J.A. Brainerd, Historic Incidents and Life in India (Chicago, IL, I867), p. 39; Forrest, A Picturesque Tour along the River Ganges, p. I24; Deane, A Tour through the Upper Provinces of Hindostan, p. I I. This was also a frequent theme of pictorial representation. In one of the eastern-India-style watercolours dated $1785-1790$, a dandy is shown preparing his dinner on the banks of the river; Shelfmark: Add. Or. 2732, Prints \& Drawings, British Library. 124. Lowrie, Travels in North India, p. 64. 
have been the dominant practice, in both types of account the strict observance of the ritual purity of food preparation is highlighted. Rather than being lowly and polluted, the dandies were said to be the zealous practitioners of ritual purity, something which was, in fact, also applicable to Muslim boatmen. ${ }^{\text {I2 }}$

\section{CONCLUSIONS}

Boatmen's work was primarily based upon the practice of contract and wage payment. Both factors suggest that there was a labour market based on the system of open hiring. The fact that the boatmen themselves were responsible for buying provisions for the long journey (they usually bought rice at two places between Calcutta and Allahabad) attests to the fact that they were wage-dependent. The duration of contracted work is important to underscore the implications of the contract. In agro-industrial production, such as that of indigo and tea, or even in the case of weaving, contracts created generational conditions of unfreedom. This seems highly unlikely to have happened for boatmen, whose duration of one "cycle of work" was much shorter.

This article has deliberately attempted to bring together two types of material: one related to work (explored through the practices of the state, regulations, market, contract, and so on) and the other to journeys (using travel accounts). The degree of dependency that existed between travelling Europeans and rowing dandies was high. This created a zone of familiarity but also mutual suspicion. The framework of the contract helps in understanding the formal "structure of work"; the minute details of the journey allow to enter into the "world of work". Clandestine trade, weather, wind, rain, torrents, tracking, mooring, internal squabbling, jocular exchanges, and, not least, preparing food were some of the main components. These details help in understanding that, within the rubric of wage relationship, other social and economic practices also thrived. The manjhee's role in illicitly carrying contraband commodities is one example. Another was the habit of dandies placing some reliance "on the produce of the fields he passes through, appropriating it, together with fire wood, and, occasionally, some stray poultry, or a kid, to the participation of his companions". ${ }^{126}$ Wages seem to have been supplemented by extra-wage earnings or appropriations.

Baksheesh (in modern-day parlance, tipping) was an important form of customary extra-wage earning. However, we do not hear of boatmen, unlike palanquin bearers, insisting on receiving baksheesh from travellers.

I 25. Lowrie expressed his surprise because all his boatmen were Muslims, but still he said, "I have to be as careful not to pollute their food by touching it in any way as if they were Hindus"; Travels in North India, p. 86.

I26. Williamson, The East India Vade-Mecum, I, p. 286. 
But there is an interesting reference given by Lowrie that suggests that boatmen tried to complement their wages through this means. ${ }^{127}$ As wages were given by the contracting agency, the manjbee had approached the missionary to lend him Rs 20. When this was denied, the missionary was approached by a dandy asking for Rs I as dustoory (customary). The fixity of wages, especially in the case of dandies who might have been experiencing precariousness due to the system of contract, perhaps forced them to invent or reinvent the practice of dustoor.

Barring caste-based criminal ethnographies, which anyway tell more about the colonial mindset than the precise historical reality, there is not enough evidence of caste- or community-based recruitment. Boatmen usually came from the Kaibarta and Mallah castes of eastern and northern India, but how far the colonial state relied on the traditional power structure of caste headmen or actively invented the authority of those headmen as service providers and recruiters is difficult to determine. Similarly, in the case of religion, boatmen were a mixed group of Hindus and Muslims. Social ties based on caste, village kinship, and religion that would have affected both the structure and world of work is a theme for further research.

The nature of work based upon mobility had an interesting characteristic and outcome. "Work" should therefore be regarded as an important category in writing the social and economic history of labour. According to one argument, because they were mobile boatmen needed advance payments, and this was seen both as a reason for and a cause of their mutinous behaviour. However, for a state that cherished the principles of sedentarization, mobility created its own set of anxieties. During early colonial rule, boatmen were gradually subjected to stringent forms of identification and regulation. One set of factors related to the nature of their work and their resistance in the form of desertion; another to the prevalence of crime in which they were seen as confidantes if not direct perpetrators. The colonial impetus to regulate and control was therefore a result of a mix of factors. The low wages and hard work that allegedly led to a "thievish" nature, the intrinsic nature of work based upon mobility, the "mutinous" solidarities formed during the journey, the variety of travel-based crime, and, not least, the state's obligation to protect both service providers and service consumers were the most important factors. Layered upon this mix was the gradual development of a caste-centric understanding that brought them further into the ambit of colonial control. ${ }^{128}$

127. Lowrie, Travels in North India, p. 65.

I28. The further consolidation of caste identity as developing alongside strategies of the independent nation state has been traced by the anthropologist Assa Doron in his writings. Apart from his Caste, Occupation and Politics mentioned above, see also Assa Doron, "Caste Away? Subaltern Engagement with the Modern Indian State”, Modern Asian Studies, 44 (2010), pp. $753-783$. 